F. Reprod. Fert. (1967) 13, 413-420

\title{
PROTEIN CONTENT OF THE MOUSE EMBRYO DURING THE FIRST FIVE DAYS OF DEVELOPMENT
}

\author{
RALPH L. BRINSTER \\ King Ranch Laboratory of Reproductive Physiology, School of Veterinary Medicine, \\ University of Pennsylvania, Philadelphia, Pennsylvania
}

(Received 4th April 1966)

Summary. The protein content of the mouse embryo decreases from $27.77 \mathrm{ng}$ at the one-cell stage to $20.58 \mathrm{ng}$ at the morula stage. This is approximately a $25 \%$ decrease during the first 3 days of development. After the morula stage, the decrease in protein content stops, and there appears to be an increase in total protein with blastocyst formation.

\section{INTRODUGTION}

In the past, several papers have appeared which have a bearing on protein synthesis in the early mouse embryo. Alfert (1950) studied protein content by means of the Millon reaction. His studies were concerned primarily with oöcytes, but he did make several observations on eggs between the 1-cell and the 4-cell stage. He felt that the protein of the 1-cell mouse egg was simply parcelled out to the cells resulting from the first few cleavages. In 1953, Flax measured changes in Fast Green staining of basic protein during early cleavage (1-cell to 8-cell stages) and found only slight changes at this time. These were not significant, although the 8-cell stage appeared to stain slightly more intensely than the 4-cell stage. More recently, Loewenstein \& Cohen (1964) measured the protein content of the 1-cell mouse egg. However, no quantitative information is available about protein content during the cleavage stages of any mammalian species. Protein content of these stages is necessary: (1) for the interpretation of respiratory studies (Fridhandler, 1961), (2) to determine specific activities in enzyme analyses (Brinster, 1965a), and (3) in interpreting in-vitro culture information (Brinster, 1965b) and autoradiographic information (Mintz, 1964) dealing with protein metabolism in the early mouse embryo. Therefore, the following studies were undertaken to determine protein content and net protein synthesis of the pre-implantion mouse embryo.

\section{MATERIALS AND METHODS}

[Considerable emphasis is placed on methods since, with the small quantities employed, attention to detail is required for accuracy and repeatability.]

\section{Obtaining embryos}

The embryos used in these studies were obtained from 8-week-old randombred female Swiss mice. These mice were superovulated by an injection of 
10 i.u. of pregnant mare serum gonadotrophin (Gestyl, Organon, Inc.) followed $48 \mathrm{hr}$ later by 10 i.u. of human chorionic gonadotrophin (HCG) (Pregnyl, Organon, Inc.). Ovulation occurs 11 to $13 \mathrm{hr}$ after HCG injection (Edwards \& Gates, 1959). At the time of the second injection, the females were placed with males, and on the following morning the females were examined for vaginal plugs as an indication of copulation. Those females with plugs were used to provide embryos of the 2-cell and later stages. Because of the large number of embryos needed for these experiments, the females without vaginal plugs were used to provide unfertilized 1-cell eggs.

Embryos of different stages of development were obtained by removing the reproductive tracts from the females at specific times after ovulation. To obtain 1-cell eggs each Fallopian tube was removed approximately $12 \mathrm{hr}$ after ovulation, placed in a Petri dish in $0.1 \mathrm{ml}$ of culture medium (Brinster, 1965c) and the ampulla was nicked with a cataract knife at the point of distension. This allowed the cumulus mass containing the eggs to escape. The cumulus mass was picked up and placed in a watch glass in $1 \mathrm{ml}$ of culture medium under liquid paraffin oil at $37^{\circ} \mathrm{C}$. When sufficient eggs (300 to 500) were obtained, they were placed in $1 \mathrm{ml}$ of hyaluronidase solution consisting of 300 units/ml of buffered salt solution (Parker, 1961), to which had been added $1 \mathrm{mg} / \mathrm{ml}$ of polyvinylpyrrolidone (mol. wt 30,000) to allow easy handling of the eggs in a solution without albumin (Brinster, 1965b). The eggs were watched during the action of hyaluronidase and as soon as the cumulus cells were dispersed, the eggs were picked up and placed in fresh culture medium. They were washed twice to remove most of the hyaluronidase before removing the albumin as described below. Two-cell embryos were obtained approximately $36 \mathrm{hr}$ after ovulation by flushing medium through the Fallopian tube from the fimbrial end as described by Brinster (1963). The embryos were picked up with a finely drawn Pasteur pipette and placed in $1 \mathrm{ml}$ of culture medium under $2 \mathrm{ml}$ of mineral oil at $37^{\circ} \mathrm{C}$. Eight-cell eggs were obtained approximately $60 \mathrm{hr}$ after ovulation in a manner similar to the 2-cell, the only difference being that about half the uterus was left attached to the Fallopian tube. Morulae and early blastocysts (blastocysts which have not hatched from their zonae pellucidae) were obtained approximately $84 \mathrm{hr}$ after ovulation by inserting a 30 -gauge needle through the wall of the uterus at the tubal end and flushing the contents of the uterus into the Petri dish. Late blastocysts were obtained approximately $108 \mathrm{hr}$ after ovulation by flushing the uterus as described for morulae and early blastocysts. The late blastocysts were particularly difficult to obtain and handle because they were free of their zonae pellucidae and extremely sticky. By $108 \mathrm{hr}$ ( 5 days after the vaginal plug) some of the embryos were beginning to stick to the wall of the uterus and flushing had to be done gently to avoid tearing the trophoblast.

\section{Washing the embryos}

All embryos were washed twice in culture medium to remove debris and red blood cells from the medium containing the embryos. If this was not done, the debris tended to adhere to the embryos in subsequent washings when the albumin was diluted in the medium. After removal of the debris, the embryos 
were washed three times in the salt solution shown in Table 1. The method of washing was to pick up all the embryos in approximately $50 \mu \mathrm{l}$ of medium (the smallest possible volume) and place them into $3 \mathrm{ml}$ of the salt solution. Finely drawn Pasteur pipettes were used, and these pipettes were selected after having been drawn for a tip diameter of about $150 \mu$ (slightly larger than the cell being transferred). The tip should be flat across $\left(90^{\circ}\right.$ with the stem) in order to pick up the embryos in a minimum fluid volume. These pipettes were siliconized after being drawn and selected. The embryos were washed in siliconized embryological watch glasses containing $3 \mathrm{ml}$ of salt solution. After each transfer, the embryos were dispersed, and the solution mixed to dilute the transferred albumin. The embryos were then picked up individually and carefully moved to the centre of the dish so that they could be picked up as a group in a small volume for the next wash. The washing was performed at a temperature of 32 to $37^{\circ} \mathrm{C}$. Three such washes in protein free medium were performed. Each wash diluted the original concentration of albumin $(1 \mathrm{mg} /$ $\mathrm{ml}$ ) by $1 / 60$ th. Therefore, the final protein concentration in the last wash was

TABLE 1

SALT SOLUTION

\begin{tabular}{l|c|c}
\hline \multicolumn{1}{c|}{ Component } & $g / l$ & $\mathrm{M} \times 10^{-3}$ \\
\hline $\mathrm{NaCl}$ & 6.975 & 119.32 \\
$\mathrm{KCl}$ & 0.356 & 4.78 \\
$\mathrm{CaCl}_{2}$ & $0 \cdot 189$ & 1.71 \\
$\mathrm{KH}_{2} \mathrm{PO}_{4}$ & $0 \cdot 162$ & 1.19 \\
$\mathrm{MgSO}_{4} \cdot 7 \mathrm{H}_{2} \mathrm{O}$ & 0.294 & $1 \cdot 19$ \\
$\mathrm{NaHCO}$ & $2 \cdot 106$ & 25.07 \\
Penicillin G (potassium) & $100 \mathrm{u} . / \mathrm{ml}$ & - \\
Streptomycin sulphate & $50 \mu \mathrm{g} / \mathrm{ml}$ & - \\
Ficoll* & 1.000 & - \\
& & \\
\hline
\end{tabular}

* Ficoll is a synthetic polymer of sucrose (Pharmacia Fine Chemicals, Inc.).

about $2 \times 10^{-5} \mathrm{mg} / \mathrm{ml}$. Conservatively, a dilution to $10^{-3} \mathrm{mg} / \mathrm{ml}$ was easily attained. From the third wash solution embryos were picked up in groups of fifty in a volume of 3 to $5 \mu$ and placed in $6 \times 50 \mathrm{~mm}$ tubes. The transfer pipette was carefully examined under a dissecting microscope after each transfer to make sure that all the embryos had been placed in the tube. The tubes containing the embryos were stored frozen at $-70^{\circ} \mathrm{C}$. When all stages had been collected, they were freeze-dried together. Samples of the salt solution and of the third wash solution were analysed with each group of embryos to act as controls.

\section{Protein determinations}

All developmental stages were represented in each set of protein determinations in order to make the data more comparable. Protein determinations were performed by the method of Lowry, Rosenbrough, Farr \& Randall (1951) with the following modifications: (1) the $\mathrm{CuSO}_{4}$ and tartrate reagent were used at twice the recommended concentration, and (2) incubation with the 
alkaline copper solution was 20 min instead of $10 \mathrm{~min}$. Human serum, the protein content of which was checked against crystalline bovine serum albumin, was used as a standard. The final analysis volume was $120 \mu \mathrm{l}$ and contained between 1 and $2 \mu \mathrm{g}$ of protein. Optical density readings were made at $750 \mathrm{~m} \mu$ in a Beckman DU spectrophotometer modified with a precision cell positioner (Greenberg \& Rodder, 1964) and microcells (Pyrocell).

\section{RESULTS}

A total of 100 protein determinations was made, representing approximately 5000 embryos of various pre-implantation stages. Table 2 summarizes the results of four series of protein determinations which included all developmental stages. It is clear from the data that a considerable fall occurs in protein content of the egg from the 1-cell stage to the morula. During the first

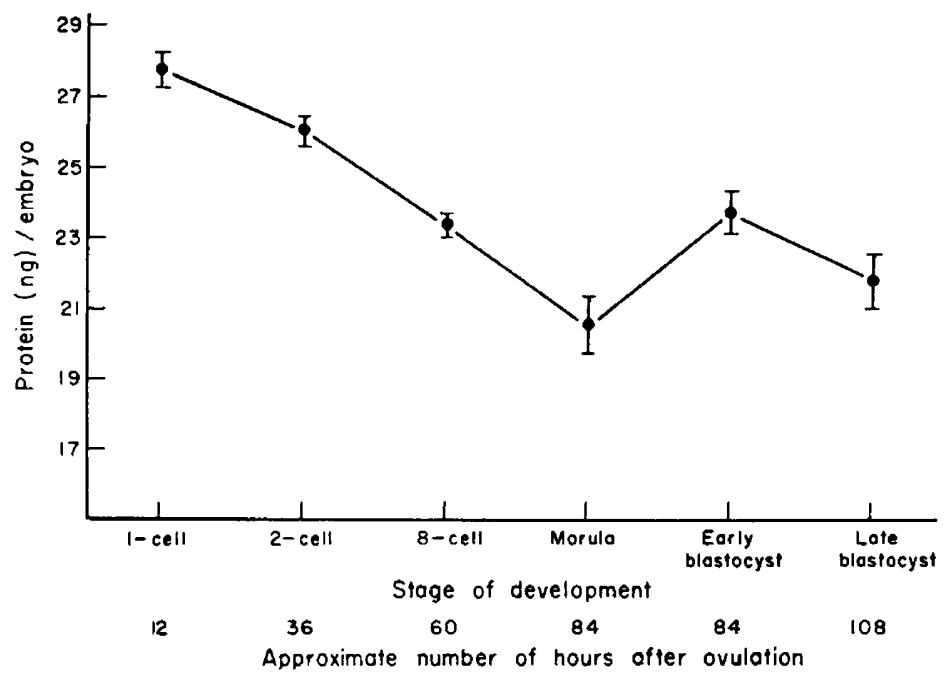

TEXT-FIG. 1. Protein content of the pre-implantation mouse embryo.

3 days of embryonic life $25.9 \%$ of the protein content of the total embryo disappears. The percentage decrease is even greater if the zona is assumed to contain a constant amount of protein. The pattern of protein loss is shown graphically in Text-fig. 1. It can be seen that the largest decrease in protein content occurs on the 2nd and 3rd day after ovulation, that is between 36 and $84 \mathrm{hr}$ after ovulation. After $84 \mathrm{hr}$, the protein content seems to increase. The content of the early blastocyst is higher than that of the morula, and the late blastocyst contains more protein than the morula when a correction is made for the absence of the zona pellucida in the late blastocyst.

The data in Table 2 have been subjected to statistical treatment to determine the significance of the protein changes. Bartlett's test for homogeneity of variance was performed on each of the developmental stages (Snedecor, 1962). The variances within each stage were homogeneous, and therefore the values could be pooled. These pooled data are shown as the summary of Table 2 . 
The average protein content of successive developmental stages was compared statistically by Student's $t$-test. In comparing the 8-cell stage with the morula, a Behrens-Fisher test was used because the standard error of the means was significantly different (Fisher \& Yates, 1963). The probability of the individual differences arising by chance is shown in Table 3. It can be seen that there is

TABLE 2

PROTEIN CONTENT OF THE MOUSE EMBRYO AT SUCGESSIVE STAGES OF DEVELOPMENT

\begin{tabular}{|c|c|c|c|c|c|c|}
\hline $\begin{array}{c}\text { Experiment } \\
\text { No. }\end{array}$ & $\begin{array}{l}\text { 1-cell } \\
\text { stage }\end{array}$ & $\begin{array}{l}\text { 2-cell } \\
\text { stage }\end{array}$ & $\begin{array}{l}\text { 8-cell } \\
\text { stage }\end{array}$ & Morulae & $\begin{array}{c}\text { Early } \\
\text { blastocysts }\end{array}$ & $\begin{array}{c}\text { Late* } \\
\text { blastocysts }\end{array}$ \\
\hline 1 & $\frac{28.90 \pm 0.71}{(7)}$ & $\left.\frac{26 \cdot 70 \pm 1}{(7)}\right)$ & $\frac{23.04}{(5)}{ }^{0.79}$ & $\underset{(2)}{18 \cdot 57 \pm 0.56}$ & $\underset{(2)}{23 \cdot 41 \pm 0.49}$ & $19 \cdot 50 \pm 1 \cdot 13 \dagger$ \\
\hline 2 & $\underset{(8)}{27 \cdot 56 \pm 1 \cdot 11}$ & $26 \cdot 46 \pm 1 \cdot 10$ & $\underset{(3)}{24 \cdot 70+0 \cdot 48}$ & $\frac{21 \cdot 06 \pm 1 \cdot 32}{(2)}$ & $\frac{26 \cdot 65 \pm 1}{(4)}$ & $20 \cdot 59$ \\
\hline 3 & $\frac{24 \cdot 41 \pm 0.64}{(4)}$ & $25 \cdot 52 \div 0 \cdot 51$ & $\frac{22 \cdot 45 \pm 0 \cdot 61}{(5)}$ & $\frac{22 \cdot 74+1.97}{(2)}$ & $\underset{(7)}{22 \cdot 62 \pm 0.48}$ & $\begin{array}{r}17 \cdot 78 \\
(1)\end{array}$ \\
\hline 4 & $\underset{(8)}{28 \cdot 69 \pm 0.67}$ & $\underset{(7)}{25 \cdot 57 \pm 0}$ & $\underset{(7)}{23 \cdot 76 \pm 0 \cdot 35}$ & $\frac{19.94 \pm 0.69}{(2)}$ & $\frac{22 \cdot 96 \pm 0.84}{(2)}$ & $\begin{array}{l}21.99+0.82 \\
(2)\end{array}$ \\
\hline Summary & $\begin{array}{c}27.77 \pm 0.51 \\
(27)\end{array}$ & $\begin{array}{c}26.08 \pm 0 \cdot 41 \\
(22)\end{array}$ & $\begin{array}{c}23 \cdot 39 \pm 0 \cdot 32 \\
(20)\end{array}$ & $\frac{20.58+0.74}{(8)}$ & $\begin{array}{c}23.85 \pm 0.63 \\
(15)\end{array}$ & $\frac{20.05 \pm 0.74}{(8)}$ \\
\hline
\end{tabular}

All values in $n g \pm$ standard error of the mean. The numbers in parentheses are the number of separate determinations.

* The late blastocyst has shed its zona pellucida, consequently $1.8 \mathrm{ng}$ (Loewenstein \& Cohen, 1964) must be added to these values when they are compared to earlier developmental stages.

$\dagger$ This group of late blastocysts was analysed at a different time than was Experiment 1.

TABLE 3

COMPARISON OF PROTEIN CONTENT IN SUCCESSIVE DEVELOPMENTAL STAGES OF THE MOUSE EMBRYO

\begin{tabular}{l|c}
\hline \multicolumn{1}{c|}{ Comparison } & $P$ \\
\hline One-cell versus 2-cell & $0.02>P>0.01$ \\
Two-cell versus 8-cell & $P<0.001$ \\
Eight-cell versus morula & $0.01>P>0.001$ \\
Morula versus early blastocyst & $0.01>P>0.001$ \\
Early versus late blastocyst & NS \\
\hline
\end{tabular}

a significant decrease in protein content with each 24-hr period of development for the first 3 days. This is followed by a rapid and significant increase in protein at blastulation. Although the value for protein content in the late blastocyst is lower than that for early blastocysts, it is not significantly less.

\section{DISCUSSION}

\section{Interpretation of results}

In comparing the data in Table 2 for the different developmental stages, four minor considerations should be borne in mind. First, all of the data on late blastocysts were obtained from embryos without their zonae pellucidae. The protein content of the zona pellucida has been determined by Loewenstein \& 
Cohen (1964) and found to be $1.8 \mathrm{ng}$. Therefore $1.8 \mathrm{ng}$ should be added to each of the figures in the late blastocyst column before comparing them with other stages. Second, the values for the 1-cell stage were determined on unfertilized eggs. Therefore, the difference between the l-cell egg of $27.77 \mathrm{ng}$ and the 2-cell egg of $26.08 \mathrm{ng}$ includes any change in protein content which may accompany fertilization as well as the change in protein from the 1-cell, fertilized, to the 2-cell stage. Third, that only about one-fourth of the morulae have two polar bodies (Lewis \& Wright, 1935). Calculations based on size indicate that, at most, the polar body loss can account for only $0.5 \mathrm{ng}$ of protein. Fourth, the protein content of the fluid in the blastocyst cavity is not known. Therefore, one is not sure how much of the increase in protein content of $3.27 \mathrm{ng}$ from the morula column to the blastocyst column in Table 2 results from protein in the fluid of the blastocyst. However, if the fluid contains $1 \mathrm{mg} / \mathrm{ml}$ of protein, which is similar to the culture medium in which the blastocysts were collected, and the size of the cavity is taken as the inner diameter of the zona $\left(3.8 \times 10^{5} \mu^{3}\right.$, Lewis \& Wright, 1935) then the protein content of the fluid is $0.38 \mathrm{ng}$.

The lower protein content of the late blastocyst in comparison with the early blastocyst is probably due to two factors. First, these embryos are zona free and are extremely sticky. This increases the chance of small cells tearing loose during the handling and sticking to pipettes and watch glasses. Second, the mouse embryo begins to stick to the uterine wall and implant during the 5th day after ovulation. It seems quite possible that the largest and most advanced embryos either were not flushed from the uterus or were broken up by the flushing. However, it should be emphasized that the protein content given is an accurate value for those whole blastocysts which are gathered at $108 \mathrm{hr}$ and used for other studies, such as enzyme analysis.

\section{Relation to other work}

The only previous biochemical determinations of protein content made on any mammalian embryos were made on the 1-cell mouse egg by Loewenstein \& Cohen (1964). They determined protein by the method of Lowry et al. (1951) and found that the 1-cell egg contained $20.2 \mathrm{ng}$ and the 1-cell, zona-free egg contained $18.4 \mathrm{ng}$ of protein. This gives a value of $1.8 \mathrm{ng}$ for the zona pellucida. The reason for the considerable difference between Loewenstein and Cohen's value and that determined in the present study is not definitely known. However, two possible explanations are: (1) they used embryos from $129 / \mathrm{J}$ mice whereas random-bred Swiss mice were used in the present study. The extent of strain differences in the embryos of mice is not known, but there very well may be differences in the amount of lipo-protein yolk material in different strains of mice. (2) Loewenstein and Cohen's method of washing the embryos to remove protein from the solution containing the embryos was quite different from the method reported here. They used buffered and unbuffered saline to wash the embryos. It was observed during the present study that embryos washed free of protein in saline washes (particularly in unbuffered saline) had a marked tendency to lyse after only two washes as described under 'Materials and Methods'. The possibility exists that some cellular protein may be lost 
during the process of washing the embryos. The more severe the washing process, the more protein is likely to be lost. The method described earlier (p. 414) has been shown not to affect viability, as washed embryos will develop if reintroduced into a suitable medium (Brinster, 1965b; Brinster \& Thomson, 1965). It seems possible that this washing process might result in less cellular protein loss than might be experienced in a polymer-free saline wash.

In 1935 Lewis \& Wright examined the size of early embryos in the mouse. They found the average volume of the vitellus of the 1-cell egg to be $1.92 \times 10^{5} \mu^{3}$. In addition, there was a decrease in volume of successive developmental stages up to the 8-cell stage which had a volume of $1.38 \times 10^{5} \mu^{3}$. This is a decrease in volume of $28.1 \%$ which is not too different from the $25.9 \%$ decrease in protein found in the present study from the one-cell to the morula. However, Lewis \& Wright found an increase in volume to $2 \cdot 19 \times 10^{5} \mu^{3}$ in the late morula. Such an increase is not incompatible with the data presented here. It seems quite probable that the increased volume of the late morula represents an increase in water content in preparation for vacuolation and blastocyst formation as described by Borghese \& Cassini (1963). Thus, there appears to be rather good agreement between the volume data of Lewis \& Wright and the protein content data reported here.

\section{ACKNOWLEDGMENT}

This work was supported by a grant from the Population Council, Inc.

\section{REFERENCES}

Alfert, M. (1950) A cytochemical study of oogenesis and cleavage in the mouse. F. cell. comp. Physiol. 36, 381 .

Borghese, E. \& CAssini, A. (1963) Cleavage of mouse eggs. Cinemicrography in Cell Biology, p. 263. Ed. E. Rose. Academic Press, New York.

BRinster, R. L. (1963) A method for in vitro cultivation of mouse ova from two-cell to blastocyst. Expl Cell Res. 32, 205.

BRINSTER, R. L. (1965a) Lactic dehydrogenase activity in the pre-implanted mouse embryo. Biochim. biophys. Acta, 110, 439.

Brinster, R. L. (1965b) Studies on the development of mouse embryos in vitro. III. The effect of fixednitrogen source. 7. exp. Zool. 158, 69.

BRINSTER, R. L. (1965c) Studies on the development of mouse embryos in vitro. IV. Interaction of energy sources. F. Reprod. Fert. 10, 227.

Brinster, R. L. \& Thomson, J. L. (1966) Development of eight-cell mouse embryos in vitro. Expl Cell Res. 42, 308.

Edwards, R. G. \& Gates, A. H. (1959) Timing of the stages of the maturation divisions, ovulation, fertilization and the first cleavage of eggs of adult mice treated with gonadotrophins. F. Endocr. 18, 292.

Fisher, R. A. \& YATEs, F. (1963) Statistical tables for biological, agricultural and medical research, 6th edn. Hafner, New York.

FLAX, M. H. (1953) Ribose nucleic acid and protein during oogenesis and early embryonic development in the mouse. Ph.D. thesis, Columbia University.

Fridhandler, L. (1961) Pathways of glucose metabolism in fertilized rabbit ova at various preimplantation stages. Expl Cell Res. 22, 303.

GReenberg, L. J. \& RodDer, J. A. (1964) New precision microcell positioner and cell holder for the Beckman model DU spectrophotometer. Analyt. Biochem. 8, 137.

LEWIS, W. H. \& WRIGHT, E. S. (1935) On the early development of the mouse ovum. Contr. Embryol. 25, 113. 
Loewenstein, J. E. \& Cohen, A. I. (1964) Dry mass, lipid content and protein content of the intact and zona-free mouse ovum. F. Embryol. exp. Morph. 12, 113.

Lowry, O. H., Rosenbrough, N. J. FARR, A. L. \& Randall, R. J. (1951) Protein measurement with the Folin phenol reagent. F. biol. Chem. 193, 265.

MinTz, B. (1964) Synthetic processes and early development in the mammalian egg. 7. exp. Zool. 157, 85.

PARKER, R. G. (1961) Methods of tissue culture, 3rd edn. Harper, New York.

SNEDECOR, G. W. (1962) Statistical methods, 5th edn. Iowa State University Press, Ames, Iowa. 